Secular Preachers, El Khachab, Page 1 of 7

\title{
Secular Preachers: Watching Television Pundits in Post-Revolutionary Egypt
}

\section{Chihab El Khachab}

Sometime in 2013, while I was doing fieldwork in Cairo, I stopped watching Egyptian television. One of the triggering events was a segment on Youssef el-Husseiny's show, el-Sada elMohtaramoun (Respectable Gentlemen), when he vehemently attacked Syrian refugees for voicing discontent about the conditions of their stay in Egypt. Imperiously gesturing in a fullfrontal shot, el-Husseiny said these refugees were not "real men" because they could not stay in Syria to fight their own dictator, because they just wanted to complain - like women, it was implied - about the country that had generously welcomed them. This remark genuinely revolted me, not only because it attacked powerless men and women who had suffered the trauma of displacement, but also because it did so in a vulgarly sexist and nationalist way. In el-Husseiny's world, Egypt is an immaculate nation in which "real men" stand and fight for their country, unlike the feminized Syrians, doubly marginalized by nationality and gender.

Although I stopped watching television, my Egyptian interlocutors did not. Most of them are upper-middle-class inhabitants of Cairo with some connection to the Egyptian film industry, the central locus of my research. The topics covered by television pundits such as el-Husseiny surfaced regularly in our conversations. El-Husseiny's show is one of many programs with a similar format on satellite channels: a single pundit sits in front of a camera for an hour or two, expressing his political views directly to an imagined audience. These shows look distinctly like sermons in which the pundit acts as a "secular preacher." Unlike Islamic televangelists, ${ }^{1}$ who give expert religious advice on the way to lead an ethical life, pundits are not literally preachers. Secular preachers seek to give expert advice on politics using similar televisual techniques, however; they are "secular" in the sense that they are explicitly against mixing religious and political practice. This overt aversion to mixing religion with politics is evidenced by all pundits' virulent attacks against the Muslim Brotherhood since Mohamed Morsi's election in 2012, and it has been an even more pronounced feature in their discourse since the 2013 military coup - or "revolution," as pundits would have it.

My progressive interlocutors and I tended to dismiss television pundits as mere ideologues who parrot the nationalist agenda of the Egyptian state and business elites. In good anthropological conscience, I have to say that our dismissal gave at once too much and too little credit to the role of television pundits in everyday political discussion in Cairo. It assumed, to begin with, that these pundits carry a monolithic voice that suppresses all dissent among ordinary audiences. This assumption is empirically erroneous because of the variations in each pundit's position since the 2011 revolution, and because of each viewer's critical engagement with these positions. Further, it ignored the mechanism through which these pundits remain relevant in the wider political conversation in Cairo.

This mechanism is comparable to the way expert religious advice, or "fatwa," is delivered to the devout Muslim. Like the devout Muslim seeking religious advice, the audience member watching a secular preacher not only agrees or disagrees with the preacher's opinions, but more importantly with the preacher's authority to express his or her opinion. This metaphorical juxtaposition between the audience member and the devout Muslim challenges liberal assumptions about free and fair political conversation. In Cairo, one's very ability to be part of the conversation is consistently attributed to an expertise which is offered, in part, by "secular preachers" on television. 
The Egyptian television landscape has undergone a major transformation since the late 1990s. The emergence of satellite television, in parallel with the rise of mobile telecommunications and the Internet, has created new space for the expression of social, political and religious opinions outside traditional mass media, which had all been under state control. Among my interlocutors in Cairo, recollections of television "in the old days" would usually stress that there were only two or three channels and everyone watched the same thing, but now there are hundreds of channels and everyone can choose what to watch. This change arguably represents a transition between the "passive" consumer, who is subject to the state's pedagogical program, and the "active" consumer, who is "free" to choose whichever channel tickles his fancy. While this choice is usually much narrower than it seems, some say the rise of satellite television has created a new "public sphere" — a space parallel to state-controlled media in which alternative political opinions can be voiced.

The democratic potential of this new sphere is sometimes overinflated because political discussion on Egyptian television is still confined to narrow, controlled channels. In effect, even when the channel is owned by a private businessman, the state retains control over much of the infrastructure allowing the channel to broadcast its signal. Since the 2013 coup, then, it has become common practice to attempt to blur the signal of satellite channels broadcasting from outside Egypt, while this situation imposes de facto limits over the kind of content available on channels broadcasting inside Egypt. Even if satellite channel owners and personnel were to disagree with the state's actions, the threat of cutting off the signal - and, by extension, its profits - is likely to be significant enough to lead satellite channels to silence "unwanted" voices on air. This is without mentioning the well-known ties between Egyptian television personnel and various secret services, which more than anything explains the sense in which television discourse has seemed to become monolithic since 2013, switching to the tune of government press releases. That said, the control maintained by the state over satellite television offers some flexibility to the pundits on air, and one can argue that the range of local, regional and international channels available on satellite television provided alternatives to state-owned television.

Satellite channels have continued to proliferate throughout the 2000s, yet the 2011 Egyptian revolution propelled the rise of new local channels and discredited national broadcasts even more. As an Egyptian colleague put it, state television was airing National Geographic documentaries about the mating habits of elephants while the occupation of Tahrir Square filled the airwaves on Al-Jazeera and CNN. In the months after Hosni Mubarak's deposition, new channels began to occupy the attention of my interlocutors: these were ONTV and CBC, local satellite channels respectively founded by business moguls Naguib Sawiris and Mohammed AlAmin. The fact that these channels became more popular in my circles is in itself indicative of the kind of company I kept: secular, liberal, bourgeois, Westernized. Had I traveled in circles closer to the Muslim Brotherhood, I might have noted the emergence of the local channel Masr 25, which droned the political line of President Morsi's party in 2012-2013 and was banned after Morsi's deposition on July 3, 2013.

What I am suggesting is that the very selection of a channel in contemporary Egypt is indicative of one's socio-political standing, much as being a Fox or NBC viewer is not merely a consumer choice, but a selection constrained by the weight of habit, political opinion and overall 
orientation to social issues. This is not to say that all audiences who watch a particular channel necessarily share the same political position: I know many interlocutors who watch Tawfik 'Ukasha, a clownish pundit on a populist channel called Al-Faraeen, to have a laugh. ${ }^{3}$ Nevertheless, the salience of ONTV and CBC among my interlocutors cannot be read as pure coincidence.

$* * *$

Youssef el-Husseiny's show aired on ONTV. Like many in my circles, I watched this channel in the aftermath of Morsi's election in 2012 until his demise in 2013. Throughout this period, elHusseiny - like many pundits on ONTV and CBC, but also on the local channels Dream, elMehwar, el-Hayah and el-Nahar - provided acerbic criticism of Morsi's government and its failure to effect any substantive change in the country's corrupt structures. El-Husseiny, like his colleagues, used a strongly secularist rhetoric in order to attack the visibly exaggerated possibility that Egypt might become an Islamic state on the Iranian model. The vehement attacks on Morsi's presidency were often directed at the Muslim Brotherhood, which was seen as the "real" governing body in Egypt, under the leadership of the organization's supreme leader, Mohammed Badie. When Morsi was ousted in 2013, el-Husseiny's rhetoric against the Muslim Brotherhood grew increasingly violent and increasingly deferential to the Egyptian military, which came to symbolize the nation against its dangerous Islamist enemies.

In the run-up to General al-Sisi's presidency, and ever since his election, television pundits such as el-Husseiny have increasingly drummed a nationalist, pro-military line, where "saving Egypt" entailed an unquestioning adherence to the military's actions. Anyone protesting its actions was commanded, fittingly, to "fall in line." In his segment on Syrian refugees, elHusseiny raged against those who, apparently, had come to Egypt in order to support the Muslim Brotherhood. Airing in the immediate aftermath of Morsi's ousting, this association between refugees and the Brotherhood was presumably meant to silence any dissent against the state through a wholesale generalization equating dissenters with Brotherhood sympathizers. This kind of equation was well received among some of my interlocutors, while others decried it. I will discuss such divergent reactions shortly; first, I wish to give a better sense of the nuances in the discourse of television pundits since the 2011 Revolution.

Egyptian television discourse has always been nationalist in scope. This is unsurprising, in a way, because television pundits are part of an intellectual milieu in which the education and modernization of the Egyptian nation are taken-for-granted objectives, as anthropologist Lila Abu-Lughod has shown for TV drama producers in Cairo. ${ }^{4}$ One might add that the television channels where pundits work share the same organizational mold; without being directly under state control, these channels are generally owned by elite businessmen with close associations to the Egyptian state. This partly explains why, in the wake of al-Sisi's presidency, voices raised against the military establishment have been slowly excluded from the television landscape. For example, anchors Reem Maged and Yousry Fouda were pushed away from ONTV; Bassem Youssef (Egypt's Jon Stewart) was successively debarred from CBC and MBC Egypt. All remaining pundits drummed a pro-military line, yet each show has retained its distinctive voice 
and appearance, creating an environment where competing "preachers" can be listened to by different flocks of "beseechers."

The distinction among television shows is partly aesthetic, partly biographical. While the general format involves a static medium-distance shot of a pundit sitting behind a desk like a preacher at a pulpit, each pundit performs a distinctive persona. Youssef el-Husseiny wears a dark suit with a light, slightly unbuttoned shirt, working at a desk surrounded by numerous television screens, thereby giving off an air of youth and professionalism characteristic of Egypt's new technocratic classes. In this respect, el-Husseiny contrasts sharply with other pundits - Khairy Ramadan (CBC), Adil Hammouda (CBC), or Mahmoud Saad (el-Nahar) who are all part of Mubarak-era media organizations: all wear austere suits, buttoned shirts and nerdy glasses. Some pundits have more idiosyncratic styles: Ibrahim Issa, a so-called rabblerouser with connections to the secret services, wears a white shirt with suspenders and small round glasses, giving him a kitschy, professorial look - and indeed, a recent program on ONTV features Issa in a mock classroom where he condescendingly explained Egyptian politics to hapless youths, an ironic comment on Egypt's generational divide.

Beyond their contrasting styles, pundits are usually recognized by name and by association with a personal history, as opposed to an identifiable ideology. This is because Egyptian television generally keeps a broadly nationalist ideological line, especially since Morsi's ousting in 2013. In consequence, Egyptian pundits are not deemed "conservative" or "liberal" as in the United States, but are usually identified with a history of positions taken since the 2011 revolution. Lamis el-Hadidy, one of the only well-known female pundits, is associated with her defense of Mubarak at the time of the Revolution, her attacks on Morsi during his presidency and her unremitting support of Abdel Fatah al-Sisi's nomination and presidency. Though one can read a clear, pro-state ideology in these positions, this ideology never determines the way pundits are generally perceived: it cannot explain how their views are decoded by television viewers.

At my father's cousin's wedding to Habi, an assistant director friend, I saw Youssef el-Husseiny in person. I was startled by his presence and asked Habi about him. He rolled his eyes and smirked, whispering that he does not like el-Husseiny either, but that he is a friend of my father's family, which is why he attended the wedding. Habi recommended that I avoid el-Husseiny as his friends had been doing; indeed, they were seated at the opposite end of the room. I relay this anecdote to show how television pundits occupy social settings similar to mine and those of my friends in the film industry — settings which are secular, liberal, bourgeois and Westernized. Furthermore, Habi's visible aversion to el-Husseiny suggests that one cannot establish a direct correlation between one's sociological profile and one's adherence to particular political opinions.

On an earlier occasion, I had discussed el-Husseiny's segment on Syrian refugees with Habi. He nodded in visible discontent, saying that he did not watch el-Husseiny anymore. I knew that Habi had watched ONTV during Morsi's presidency; some of his friends even work at this channel. Yet, he does not always agree with the opinions expressed on ONTV. Moreover, Habi's appraisal of el-Husseiny goes beyond ideological branding. Habi could have said that he dislikes el-Husseiny for being a nationalist hack, yet he chose to say that he does not like him anymore, implying that he used to agree with his positions on the Muslim Brotherhood during Morsi's 
presidency but that he does not agree with his strongly militarist rhetoric in the post-Morsi era. This illustrates that television pundits are not merely dubbed "nationalist" or "Islamist" by their audiences. Instead, they are associated with a well-known history of positions, with which their audiences engage critically.

Such critical engagement is evident even in the case of viewers who agree with television pundits. A striking example is my grandmother, Touta, a retired Arabic schoolteacher. Because she cannot travel outside her apartment without assistance, Touta spends her days watching television, mostly Egyptian talk shows, Turkish serial dramas, some "moderate" televangelists and some political pundits. On my visits in early 2013, while Morsi was still president, Touta liked to watch Moataz el-Demerdash, a well-known talking head then on el-Hayah network. She particularly liked his antipathy to the Muslim Brotherhood, to which she was particularly averse, arguing (as many television pundits did) that they pretend to govern in the name of Islam without practicing Islamic virtues. A pious Muslim, Touta said that the Brotherhood had no business telling her how to practice her religion, or what she should do as a woman, both prominent features in the discourse of the Morsi government.

When I returned to Cairo later in 2013, after Morsi had been deposed, my grandmother had stopped watching el-Demerdash because he was now "too soft" — by which she meant that he was not critical enough of the "terrorist" Muslim Brotherhood, a term she likely picked up from television. Touta even started watching Al-Qahira wal-Nas (Cairo and the People), a farright channel with even more aggressive pro-military pundits. On a side note, this channel is owned by Tarek Nour, an advertising mogul and head of al-Sisi's electoral campaign. Touta might have changed her viewing preferences out of boredom, as she spends a great deal of time watching television, yet boredom alone cannot explain why she started watching more aggressive pundits. As I see it, Touta's change of heart (and programs) was not caused by a shift in el-Demerdash's ideology, because he arguably engages in the same nationalist rhetoric as all Egyptian pundits. Instead, it is the relative moderation of el-Demerdash's stance toward the Muslim Brotherhood that led Touta to watch pundits whose attacks on the Brotherhood were more vehement. What drew her attention, in sum, is the force of the preacher's sermon, not its propositional content.

I do not wish to imply that this critical engagement with television discourse is only possible for "educated" audience members, such as Habi or Touta. My high-school educated childhood nanny, Dina, likes to watch Gaber el-Armouti on ONTV. When I asked her why she likes his show, she answered that it is because el-Armouti is a sincere man; he tries to speak the truth to the audience and brings evidence "on paper" (i.e., by screening quotes from major newspapers and government reports) to support his claims. In my arrogance, I was tempted to tell Dina that she does not understand politics well enough to see how el-Armouti is conveying a pro-military line which, in some respects, goes against her working-class interests. I refrained, however, partly because Dina's political opinion is probably that the military and the government are ultimately forces for good, and partly because Dina is well aware that el-Armouti uses evidence to sustain his claims. In other words, Dina is not under the spell of false consciousness when she watches television. She critically engages with each pundit's claims and identifies elArmouti as better because he summons tangible evidence, "on paper," however much someone like me disagrees with his show's framing and content. 
It is precisely with respect to the "evidential" nature of pundits' expertise that one can call them "secular preachers" and compare their punditry to a fatwa. One might be tempted to associate the term fatwa with a powerful edict carrying the force of "law" in Islam. This is not the case with any fatwa, however, because its force largely relies on the authority of the expert who expresses what, in effect, is a legal opinion. Salman Rushdie's persecution was not mandated because there was a fatwa against him but because this fatwa was pronounced by Ayatollah Khomeini, a highly authoritative figure in the Shiite Islamic world. I am not saying that television pundits have the same authority as religious specialists, but I am saying that their "secular" sermons are variously interpreted and judged by ordinary television viewers, who are not so much interested in assessing the sermon's content as they are in assessing its impact and authority given a certain evidential standard.

This standard is not exclusively within the pundit's purview: it is shared by the preacher and his audience, who is ultimately in charge of assessing the evidence - or more exactly, the authority of the evidence - presented by television pundits. In Cairo, the word fatwa and its corollary, fatyi, are used in the more profane sense of "expressing a baseless opinion." When someone is said to engage in fatyi, it means the person is talking "out of their hat." This meaning is instructive in explaining what the preacher is doing when giving a fatwa. His opinion, like anyone else's fatyi, is always potentially baseless, but it is his religious authority and expertise that lends such opinions some credence.

This is where the analogy between the preacher and the pundit lies. Televised "sermons" can always be rejected by viewers as mere conjecture - in the same way as Habi, my assistant director friend, disagreed with Youssef el-Husseiny. It is in recognizing the preacher's authority that the audience affirms the sermon. In Islam, this authority is ultimately bestowed by the Quran and the Prophet's sayings, but the individual beseecher has some leeway in determining whether he will listen to a particular preacher or not. This is also the case with television pundits whose audiences clearly distinguish between whom they will and will not "listen to." I find this creates a situation where political conversation is not so much a matter of expressing one's opinion in a liberal public sphere as a matter of constantly justifying one's opinion by appeal to the expertise of a "secular preacher."

To be sure, watching television is not the only way people justify and support their political opinions; one might appeal to the authority of someone other than a television pundit. What remains clear, however, is that Egyptian pundits act like experts in national political matters and their audiences critically engage with their discourse in ways that sustain this claim to expertise. Dina not only likes to listen to Gaber el-Armouti but, by listening, she defers to his expertise on political matters in recognizing the authority of what she takes to be his "evidence." Claims to expertise are not only encoded in television discourse but also sustained by viewers in a manner akin to that of the fatwa's beseecher. Thus, secular preachers arguably embody what political theorist Tim Mitchell calls the "rule of experts" in Egypt".

\section{Notes}

\footnotetext{
${ }^{1}$ Yasmin Moll, 2010, "Islamic Televangelism: Religion, Media, and Visuality in Contemporary Egypt," Arab Media \& Society, 10: 1-27.

${ }^{2}$ Dale F. Eickelman and Jon W. Anderson (eds.). New Media in the Muslim World: The Emerging Public Sphere (Bloomington: Indiana University Press, 1999.
} 
${ }^{3}$ On 'Ukasha, see Walter Armbrust, 2013. "The Trickster in Egypt's January 25 ${ }^{\text {th }}$ Revolution," Comparative Studies in Society and History, 55 (4): 834-864.

${ }^{4}$ Lila Abu-Lughod. Dramas of Nationhood: The Politics of Television in Egypt (Chicago: University of Chicago Press, 2005.

${ }^{5}$ Tim Mitchell, 2002, Rule of Experts: Egypt, Techno-Politics, Modernity (Berkeley: University of California Press).

Chihab El Khachab is a D.Phil. candidate in anthropology in Wolfson College, University of Oxford. His dissertation examines how new media technologies such as smartphones, laptops and cameras are used in the everyday working practices of the Egyptian film industry. 